\title{
The Study of Intelligence Profiles Between Islands: A Preliminary Study Towards Norm Development
}

\author{
Andika Octavianto, Mohammad A. G. Priadi, \\ and Magdalena S. Halim \\ Faculty of Psychology \\ Atma Jaya Catholic University of Indonesia \\ Indonesia
}

\author{
Christiany Suwartono \\ Faculty of Psychology \\ Atma Jaya Catholic University of Indonesia \\ Donders Institute for Brain, Cognition and Behavior, \\ Radboud University, Nijmegen \\ The Netherlands
}

\begin{abstract}
The aim of this study was to compare the intelligence of Indonesians residing in different islands using the Indonesian WAIS-IV (WAIS-IV-ID), which could be further considered in standardized norm development. Statistical analyses using ANOVAs were performed on the 15 subtests, four indices, and the Full-Scale Intelligence Quotient (FSIQ) of the WAISIV-ID. This study involved 506 healthy participants, the majority were females, in productive age-groups ranging from 16 to 59 years old, and from middle educational background. Results showed that three indices and 13 subtest scores had significant results and the sample from Java Island had significantly higher scores than the sample from Sumatra, Borneo, and Sulawesi Islands. Based on the conducted analysis, the normative data of the WAIS-IV-ID need to be classified differently between islands or between Java Island and Non-Java Island for more accurate score interpretation. The interpretations and implications of the findings are discussed.
\end{abstract}

\section{Keywords: WAIS-IV, intelligence profiles, islands, Wechsler scale, Indonesia}

Tujuan penelitian ini adalah membandingkan kecerdasan masyarakat Indonesia yang tinggal di pulau yang berbeda dengan menggunakan WAIS-IV-ID untuk masukan dalam pembuatan standardisasi (norma) WAIS-IV-ID ini. Pengujian statistik dilakukan dengan analisis ANOVA untuk 15 subtes, empat indeks, dan Full-Scaled Intelligence Quotient (FSIQ) dari WAIS-IV-ID. Penelitian ini melibatkan 506 partisipan dari populasi normal, dengan mayoritas berjenis kelamin perempuan, usia produktif 16-59, dan latar belakang pendidikan menengah. Hasil menunjukkan bahwa tiga indeks dan 13 subtes memiliki perbedaan yang signifikan dan sampel yang berasal dari Pulau Jawa memiliki skor signifikan lebih tinggi bila dibandingkan sampel dari Sumatera, Kalimantan, dan Sulawesi. Berdasarkan analisis yang dilakukan, data normatif perlu diklasifikasikan berbeda antarpulau atau antara Pulau Jawa dan Non-Pulau Jawa untuk interpretasi yang lebih akurat dari skor-skor WAIS-IV-ID. Rekomendasi lebih lanjut tersebut telah dibahas.

Kata kunci: WAIS-IV, profil kecerdasan, pulau-pulau, skala Wechsler, Indonesia

The Wechsler scale of intelligence is one of the most widely used tools for intelligence measurement (Camara, Nathan, \& Puente, 2000). The original version of the Wechsler intelligence test, the Wechsler-Bellevue Intelligence Scale (WBIS) was developed in 1939 and has changed several times. Internationally, the WBIS was changed into the WAIS, WAIS-R, WAIS-III, and finally, the latest

Correspondence concerning this article should be addressed to Andika Octavianto or Christiany Suwartono, Faculty of Psychology, Atma Jaya Catholic University of Indonesia, Jakarta, Indonesia. Email: andikaoctavianto@gmail.com or christiany.suwartono@atmajaya.ac.id version of Wechsler Intelligence measurement tools is the WAIS-IV (Lichtenberger \& Kaufman, 2009). Besides measuring intelligence, the WAIS-IV is widely used in clinical settings, such as for measuring cognitive functions (Baxendale, 2011) and epilepsy (Baxendale, McGrath, \& Thompson, 2014). Because of the advantages of this measurement tool, the WAIS-IV has been adapted by many countries, including Indonesia (Suwartono, Halim, Hidajat, Hendriks, \& Kessels, 2014).

Indonesia is one of the countries that have adapted the WAIS-IV. The adaptation is important because 
of the lack of intelligence measurement tools and well-validated normative data in Indonesia. The United States version of WAIS-IV (WAIS-IV-US) was released in 2008. However, the adaptation process of the Indonesian version (WAIS-IV-ID) was only started in 2012. The item sequence of several subtests of the WAIS-IV-ID was reordered because of differences in item difficulties when compared to those in the WAIS-IV-US, although the number of items and contents were still the same (Suwartono et al., 2014). The first psychometric evaluations of the WAIS-IV-ID that have been conducted in several studies (Suwartono et al., 2014; Suwartono, Hendriks, Hidajat, Halim, \& Kessels, 2015; Suwartono, Hendriks, Hidajat, Halim, \& Kessels, 2016) showed that the Cronbach's alpha coefficients of reliability for the WAIS-IV-ID subtests ranged from .74 to .92 , it had the same internal structure as the WAIS-IV-US and external validity with other intelligence tests and educational achievement. The results indicate that the WAIS-IV-ID has promising psychometric properties; that is, good reliability and validity.

The next step would be preparing the norming or standardization of the test score. The standardization of the WAIS-IV-ID is required as the next psychometrics evaluation. Cockcroft, Alloway, Copello, and Milligan (2015) stated that standardized normative scores from a western country population (UK) were still used in the intelligence assessment of black South African (SA) population despite its lacks of measurement invariance between the two groups. The UK group significantly outperformed the SA group on the verbal comprehension, and several non-verbal subtests, while the SA group performed significantly better on the measures of Processing Speed (PS). Shuttleworh-Edwards, Kemp, Rust, Muirhead, Hartman, and Radloff (2004) found that the score discrepancy of the black South Africans was up to 20 points lower than the white South African with an advantaged educational level based on the western standardized norm.

Another research by Harrison, Armstrong, Harrison, Lange, and Iverson (2014) showed that the standardized normative scores of the Canadian version of WAIS-IV were lower than those of the WAIS-IVUS. Harrison et al. (2014) suggest that Canadian psychologists use a careful approach in interpreting intelligence scores using American norms. Thus, previous studies (Cockcroft et al., 2015; Harrison et al., 2014; Shuttleworh-Edwards et al., 2014) showed that developing a standardized norm for a country is essential for the interpretation process of individual scores. Unfortunately, mostly, there was limited information or publications about the standardized norms of any measurement tools in Indonesia. Current publications on standardized norms are mostly unclear both regarding the person in charge and the period of data collection. This indicates an urgent need to develop standardized norms for the Indonesian psychological measures, especially the WAISIV-ID, to provide a valid interpretation of intelligence scores.

More than a half of Indonesians (57.49\%) live in Java Island (Badan Pusat Statistik - BPS, 2016a). However, the WAIS-IV-ID standardized norms should not only be based on the scores of participants from Java Island. The use of a single norm might bias the interpretation of the WAIS-IV-ID scores of people living outside Java Island. Urbina (2004) stated an interpretation of scores should be based on the normative scores of people from the same groups where the data were collected. If the scores are compared and interpreted using other groups' normative scores, then the usefulness of measurement tools is reduced (Groth-Marnat, 2010).

Santrock (2013) stated that several factors could influence intellectual development. Genetic and environmental factors contributed to score differences in intelligence (Lynn, 2006; Nisbett, 2009; Rushton \& Jensen, 2005). Thus, ideal conditions for cognitive development can be different among people in the main islands of Indonesia and allegedly, this might be caused by inequality development in cognitive functions. Kuncoro (2013) argued that the development in the main islands of Indonesia is varied. A rapid economic development in Java Island leads to better development in education, health, and other aspects that indirectly influence people's cognitive development. This can be seen from Java's Human Development Index (HDI) that is considered as the highest in Indonesia. Notably, the HDI measures the average achievements in longevity (life expectancy at birth), knowledge (combination of adult literacy rate and mean years of schooling), and standard of living (real income per capita; Kusharjanto \& Kim, 2011). More specifically, data from BPS (2016b), which is based on Indonesia's HDI in 2015 showed that almost all the provinces in Java Island had higher scores than those in non-Java islands, meaning that people in Java had a better quality of living as measured by the quality of education, health, age, and wealth. The inequality development between the main islands in Indonesia was allegedly impacted people's cognitive development. Using these argu- 
ments, we argue that obtaining data from people outside Java is necessary for the representation of standardized norms of the WAIS-IV-ID.

Considering that education is an important variable for intelligence development, we are concerned about the lack of education of people from outside Java Island. A national newspaper reported that Borneo island still lacks of teacher staff, there were about 10,000 positions for teachers needed ("Kalimantan Barat, 2015"). During data collection, the first author found that the distance between people's home and the school had become a barrier that prevents the residents from having an education. A student's home was about four kilometres from the school in a remote area; this made parents decide not to send their children to school ("Jumlah Sekolah", 2015).

Moreover, research by Flynn (cited in Nisbett et al., 2012) found that the increased IQ scores in a global scope were influenced by numerous factors, including a better development, education, and nutrition. Java Island, as the central of development in Indonesia compared with other islands in Indonesia, has indirectly affected the intelligence scores of Indonesians, where people living in Java Island might have better performances on the WAIS-IV-ID. Based on this condition, the standardization of psychological measurement tools in Indonesia should be well considered so it can represent the real nature of Indonesian people. This requires data collection from people living in other islands in Indonesia, thus, not only relying on data from Java island where the majority people live, in order to develop the standardized norms of the WAIS-IV-ID. Unfortunately, even though Indonesia consists of five main islands, this study obtained data only from four main islands. In the present study, we compared the intelligence profiles among Indonesians residing in different islands using the WAIS-IV-ID.

We used the WAIS-IV-ID to examine the possibility of intellectual profile differences among Indonesians residing in four main islands. The WAISIV-ID is an individual test, administered to people aged 16 to 90 years. The WAIS-IV-ID contains 15 subtests, namely Block Design (BD), Similarities (SI), Digit Span (DS), Matrix Reasoning (MR), Vocabulary (VC), Arithmetic (AR), Symbol Search (SS), Visual Puzzle (VP), Information (IN), Coding (CD), Letter Number Sequencing (LN), Figure Weight (FW), Comprehension (CO), Cancellation (CA), and Picture Completion (PC; Lichtenberger \& Kaufman, 2009). The WAIS-IV-ID has four index scores: Verbal Com- prehension Index (VCI), Perceptual Reasoning Index (PRI), Working Memory Index (WMI), and Processing Speed Index). As a general intellectual functioning, the WAIS-IV-ID provides the Full-Scale Intelligence Quotient (FSIQ). This study aimed to compare the intelligence profiles among Indonesians residing in four main islands and to provide recommendations regarding the norming for adequate interpretation of the WAIS-IV-ID. This study did not only report descriptions of subtests and indices of the WAIS-IV-ID, but also provided recommendations regarding further development necessary for those living in other regions in Indonesia, especially in education and healthcare sector outside Java which can indirectly influence cognitive development of Indonesians.

\section{Method}

\section{Participants}

We used a convenience sampling to obtain participants in the four main islands in Indonesia. The inclusion of participants was followed the requirements listed in the WAIS-IV Technical and Interpretive Manual (Wechsler, 2008). The present study involved 506 individuals in total: 159 (31.42\%) participants from Java Island, 136 (26.88\%) participants from Sumatra Island, 111 (21.94\%) participants from Sulawesi Island, and $100(19.76 \%)$ participants from Borneo Island. The participants' age ranged from $16-59$ years old $(M=26.61 ; S D=9.20)$, with $7.5 \%$ participants completed junior high school, 50.19\% completed senior high school, and $42.31 \%$ participants had a diploma or bachelor degree. The majority $(55.53 \%)$ of participants were females. We tried to closely represent the population density of each island (Java, Sumatra, Sulawesi, and Borneo) in our sample. We also sought to represent the distribution of males $(49.86 \%)$ and females $(50.14 \%)$ in the Indonesian population (Badan Pusat Statistik, 2016a). Octavianto collected data in Pontianak, the West Borneo Province and the remaining data (Sumatra, Sulawesi, Java, and other Borneo provinces) were gained from the normative data of WAIS-IV-ID which had been collected previously (in the period of 20132015, coordinated by Suwartono).

Educational attainment was represented in years of education. The educational data were separated into three categories, that is, Junior High School (nine years), Senior High School (12 years), and Higher 
Education (> 12 years). The age category was created based on developmental stages: adolescence, young adulthood, and middle adulthood (Santrock, 2013). Additionally, the age category was based on the intelligence theory; Lichtenberger and Kaufman (2009) found that intelligence development still significantly increases between the age of 16-20 in adolescence phase, then between the age of 21-30 and 31-40 in adulthood, the intelligence tends to be stable, and between the age 41-59 in middle adulthood, the intelligence declines slowly.

\section{Instrument}

We used the Wechsler Adult Intelligence ScaleFourth Edition (WAIS-IV-ID; Suwartono et al., 2014; Wechsler, 2008). The WAIS-IV consists of 15 subtests and provides a measurement of general intellectual functioning (FSIQ) and four index scores: Verbal Comprehension (VCI), Perceptual Reasoning (PRI), Working Memory (WMI), and Processing Speed (PSI). The index scales include core and supplemental subtests. The VCI comprises three core subtests (SI, VC, and IN) and one supplemental subtest (CO). The PRI includes three core subtests (BD, $\mathrm{MR}$, and VP) and two supplemental subtests (FW and PC). The WMI comprises two core subtests (DS and AR) and one supplemental subtest (LN). The PSI consists of two core subtests (SS and CD) and one supplemental subtest (CA). We administered the 15 subtests and applied the discontinue rules. The administration of the subtests stopped after several zero scores because participants' answer was different from the scoring key in the manual (Wechsler, 2008). The raw scores were converted using the American norms because the Indonesian norms have not yet established.

\section{Procedures}

This study is part of a larger study by Suwartono. For data collection, we collaborated with schools, universities, local offices, consulting firms, and foundation. The authors sent the introduction letter to the institutions, asking permission to collect data and requesting a schedule for data collection. After the permission was granted from the institutions, the authors made an appointment with potential participants from the institutions. We explained to participants that we planned to make the test adaptation (WAIS-IV-ID) and the test would be individually administered. The participant was voluntary involved in data collection by completing an informed consent before the assessment started. The assessment process was conducted in the institutions' counseling or meeting room. The room was controlled in such a way as to prevent distractions, noises, and interruptions during data inquiry. The administration of the WAIS-IV-ID took 60-120 minutes and testers wrote participants' responses in prepared response sheets.

\section{Analysis}

Statistical analysis used in this study was descripttive statistics. We used figures, and tables to present data. Descriptive statistics were used to describe profiles of each subtest in the WAIS-IV-ID. We then checked for normality in each data subsets, testing the significance of skewness and kurtosis (Corder \& Foreman, 2009). The normality tests showed that all data subsets in the four islands were normally distributed. Therefore, we used parametric statistical analysis, a one-way ANOVA. A one-way ANOVA is a parametric statistical technique used to test mean differences between two or more groups of samples (Gravetter \& Wallnau, 2013). Further, Scheffé's method was used as a post hoc test. We then compared the scores of each index and subtest between samples from different islands. We also performed a twoway ANOVA between islands and levels of education.

\section{Results}

Descriptive statistics of intelligence indices and the Full-Scale IQ (FSIQ) are illustrated in Figure 1.

In general, the highest index scores were found in Java sample, and the lowest index scores were found in Borneo sample. Table 2 provides details of the index and subtest means of the WAIS-IV-ID in the four islands.

As shown in Table 2, the Java sample had the highest subtest scores, except for CO, SS, and CA. In this case, the highest scores were gained from the Sulawesi sample. The Borneo sample had the lowest scores in all the WAIS-IV-ID subtests, except for VP, FW, AR, LN, and CD. The Sumatra sample had the lowest scores on VP, FW, and LN, whereas the Sulawesi sample had the lowest scores on AR and CD. However, when a series of one-way ANOVAs was performed, the means differences on PSI, SS, and CA between samples from different islands were 
Table 1

Demographic Characteristics of Participants

\begin{tabular}{|c|c|c|c|c|c|c|c|c|}
\hline \multirow{2}{*}{ Category } & \multicolumn{8}{|c|}{ Number of Participants } \\
\hline & Borneo & $\%$ & Java & $\%$ & Sumatra & $\%$ & Sulawesi & $\%$ \\
\hline \multicolumn{9}{|c|}{ Demographic data } \\
\hline Male & 37 & 37 & 68 & 42.77 & 64 & 47.06 & 56 & 50.45 \\
\hline Female & 63 & 63 & 91 & 57.23 & 72 & 52.94 & 55 & 49.55 \\
\hline \multicolumn{9}{|c|}{ Years of Education } \\
\hline 9 years & 7 & 7 & 18 & 11.32 & 8 & 5.88 & 5 & 4.50 \\
\hline 12 years & 36 & 36 & 76 & 47.79 & 70 & 51.47 & 72 & 64.86 \\
\hline$\geq 12$ year & 57 & 57 & 65 & 40.88 & 58 & 42.65 & 34 & 30.63 \\
\hline \multicolumn{9}{|c|}{ Age $(M=26.61 ; S D=9.20)$} \\
\hline $16-20$ & 13 & 13 & 32 & 20.13 & 39 & 28.68 & 33 & 29.73 \\
\hline $21-30$ & 42 & 42 & 105 & 66.04 & 80 & 58.82 & 59 & 53.15 \\
\hline $31-40$ & 17 & 17 & 13 & 8.18 & 10 & 7.35 & 9 & 8.11 \\
\hline $41-59$ & 28 & 28 & 9 & 5.66 & 7 & 5.15 & 10 & 9.01 \\
\hline$M$ & 26.34 & & 26.55 & & 26.52 & & 26.66 & \\
\hline$S D$ & 9.18 & & 9.24 & & 9.26 & & 9.39 & \\
\hline
\end{tabular}

not significant.

Based on the means shown in Table 2, we analyzed the subtest and index scores of Indonesian people in the four main Islands using a series of oneway ANOVA tests. We found that there were significant results on 13 subtests $\left(\mathrm{SI}: F_{(3,502)}=14.78, p<\right.$ .01 ; $\mathrm{VC}: F_{(3,502)}=9.98, p<.01 ; \mathrm{IN}: F_{(3,502)}=10.63$, $p<.01$; $\mathrm{CO}: F_{(3,502)}=7.83, p<.01$; $\mathrm{BD}: F_{(3,502)}=$ 5.01, $p<.01$; MR: $F_{(3,502)}=11.67, p<.01$; VP: $F_{(3,}$ ${ }_{502)}=4.23, p<.01$; FW: $F_{(3,502)}=11.29, p<.01$; PC: $F_{(3,502)}=10.30, p<.01 ; \mathrm{DS}: F_{(3,502)}=17.10, p<.01$; AR: $F_{(3,502)}=20.70, p<.01 ; \mathrm{LN}: F_{(3,502)}=9.55, p<$ .01 ; CD: $\left.F_{(3,502)}=6.26, p<.01\right)$. Furthermore, we found that three index scores (VCI: $F_{(3,502)}=30.20$, $p<.01$; PRI: $F_{(3,502)}=18.68, p<.01$, WMI: $F_{(3,502)}$ $=35.62, p<.01)$ and the Full-Scale IQ (FSIQ: $F_{(3}$, $\left.{ }_{502)}=27.35, p<.01\right)$ were significantly different among Indonesian samples in the four main islands. The results showed that there were differences in the intelligence profiles among the Indonesian samples in the four main islands. Then, using Scheffé's post hoc tests, we found that people residing in Java Island had significantly higher scores compared to people in the three main islands.

We conducted additional analyses between islands and education as seen in Table 3.

We found that there were no significant differrences in working memory between people from different educational backgrounds. There was also no significant interaction between islands and levels of education in working memory and processing speed. Figure 2 provides visualization of the interactions between islands and levels of education.

The two-way ANOVA tests revealed a significant main effect on VCI for Islands, $F_{(3,502)}=32.77, p<$ .01 and for educational background, $F_{(2,503)}=19.89$, $p<.01$. Moreover, there was a significant interaction between island and education on VCI, $F_{(6,499)}=5.31$, $p<.01$. We also found that there was a significant main effect for Islands, $F_{(3,502)}=11.01, p<.01$; a significant main effect for educational background, $F_{(2,503)}=7.57, p<.01$; and a significant interaction between island and education on PRI, $F_{(6,499)}=3.21$, $p<.01$. The analyses on the Full-Scale IQ showed that there was a significant main effect for Islands, $F_{(3,502)}=20.57, p<.01$; a significant main effect for educational background, $F_{(6,499)}=16.32, p<.01$; and a significant interaction between island and education on the Full-Scale IQ, $F_{(6,499)}=3.16, p<.01$. The results indicate that educational background influenced the VCI, PRI, and FSIQ among Indonesian samples in the four main islands. Using Scheffé's post hoc tests, we found that people with higher educational backgrounds and lived in Java Island had significantly higher scores on VCI, PRI, and the FSIQ compared to people who lived in the other 
Table 2

ANOVA and Means Index and Subtest Scores Among Samples Residing in Four Islands in Indonesia.

\begin{tabular}{|c|c|c|c|c|c|c|}
\hline \multirow{2}{*}{ WAIS-IV-ID } & \multicolumn{2}{|c|}{ Islands } & \multirow{2}{*}{$\begin{array}{c}\text { Borneo } \\
(M)\end{array}$} & \multirow{2}{*}{$\begin{array}{c}\text { Java } \\
(M)\end{array}$} & \multirow{2}{*}{$\begin{array}{r}\text { Sumatra } \\
(M)\end{array}$} & \multirow{2}{*}{$\begin{array}{r}\text { Sulawesi } \\
(M)\end{array}$} \\
\hline & $F$ & Sig & & & & \\
\hline FSIQ & 27.35 & $.00 * *$ & 84.01 & 96.4 & 87.2 & 88.09 \\
\hline$V C I$ & 30.20 & $.00 * *$ & 83.41 & 94.61 & 88.9 & 90.27 \\
\hline$S I$ & 14.78 & $.00^{* *}$ & 6.56 & 8.40 & 7.57 & 7.63 \\
\hline$V C$ & 9.98 & $.00 * *$ & 8.36 & 10.72 & 9.66 & 9.89 \\
\hline IN & 10.63 & $.00 * *$ & 6.20 & 8.04 & 6.77 & 7.27 \\
\hline $\mathrm{CO}$ & 7.83 & $.00 * *$ & 5.68 & 6.87 & 6.91 & 7.46 \\
\hline$P R I$ & 18.68 & $.00 * *$ & 86.11 & 96.55 & 87.47 & 89.00 \\
\hline$B D$ & 5.01 & $.00 * *$ & 7.92 & 8.95 & 8.11 & 8.34 \\
\hline$M R$ & 11.67 & $.00 * *$ & 6.76 & 9.55 & 7.39 & 7.67 \\
\hline$V P$ & 4.23 & $.01 * *$ & 8.21 & 9.84 & 8.06 & 8.38 \\
\hline$F W$ & 11.29 & $.00^{* *}$ & 8.42 & 10.72 & 8.04 & 9.24 \\
\hline$P C$ & 10.30 & $.00 * *$ & 5.38 & 7.61 & 6.51 & 6.04 \\
\hline$W M I$ & 35.62 & $.00 * *$ & 84.53 & 98.63 & 86.08 & 85.47 \\
\hline$D S$ & 17.10 & $.00 * *$ & 7.42 & 9.93 & 7.86 & 7.99 \\
\hline$A R$ & 20.70 & $.00 * *$ & 7.15 & 9.64 & 7.27 & 6.9 \\
\hline$L N$ & 9.55 & $.00 * *$ & 8.79 & 10.32 & 8.68 & 9.01 \\
\hline$P S I$ & 2.38 & .07 & 95.47 & 100.2 & 97.36 & 96.72 \\
\hline$S S$ & 1.70 & .16 & 9.45 & 9.92 & 9.75 & 10.11 \\
\hline$C D$ & 6.26 & $.00^{* *}$ & 8.88 & 10.14 & 9.25 & 8.72 \\
\hline$C A$ & 2.16 & .09 & 8.16 & 8.21 & 8.47 & 9.02 \\
\hline
\end{tabular}

Table 3

Index Scores Analyses Between Main Islands and Education

\begin{tabular}{lcccccr}
\hline \multirow{2}{*}{ WAIS-IV Indices } & \multicolumn{2}{c}{ Islands } & \multicolumn{2}{c}{ Education } & \multicolumn{2}{c}{ Islands*Education } \\
\cline { 2 - 6 } & $F$ & Sig & $F$ & Sig & $F$ & Sig \\
\hline Verbal Comprehension (VCI) & 32.77 & $.00^{* *}$ & 19.89 & $.00^{* *}$ & 5.31 & $.00^{* *}$ \\
Perceptual Reasoning (PRI) & 11.01 & $.00^{* *}$ & 7.57 & $.00^{* *}$ & 3.21 & $.01^{* *}$ \\
Working Memory (WMI) & 18.17 & $.00^{* *}$ & 2.48 & .08 & .739 & .61 \\
Processing Speed (PSI) & 2.71 & .04 & 19.19 & $.00^{* *}$ & 1.94 & .07 \\
Full-Scale IQ (FSIQ) & 20.57 & $.00^{* *}$ & 16.32 & $.00^{* *}$ & 3.16 & $.01 * *$ \\
\hline
\end{tabular}

three main islands and who had lower educational backgrounds.

\section{Discussion}

The aim of this study was to compare the intelligence profiles among Indonesian samples residing in different islands using the Indonesian version of WAIS-IV (WAIS-IV-ID). This study is a preliminary study to form the standardization of the WAIS-IVID scores; in particular, we would like to have an overview of the test scores among people residing in four main islands in Indonesia. The results showed that there were significant differences in intelligence profiles among Indonesian samples in Java, 


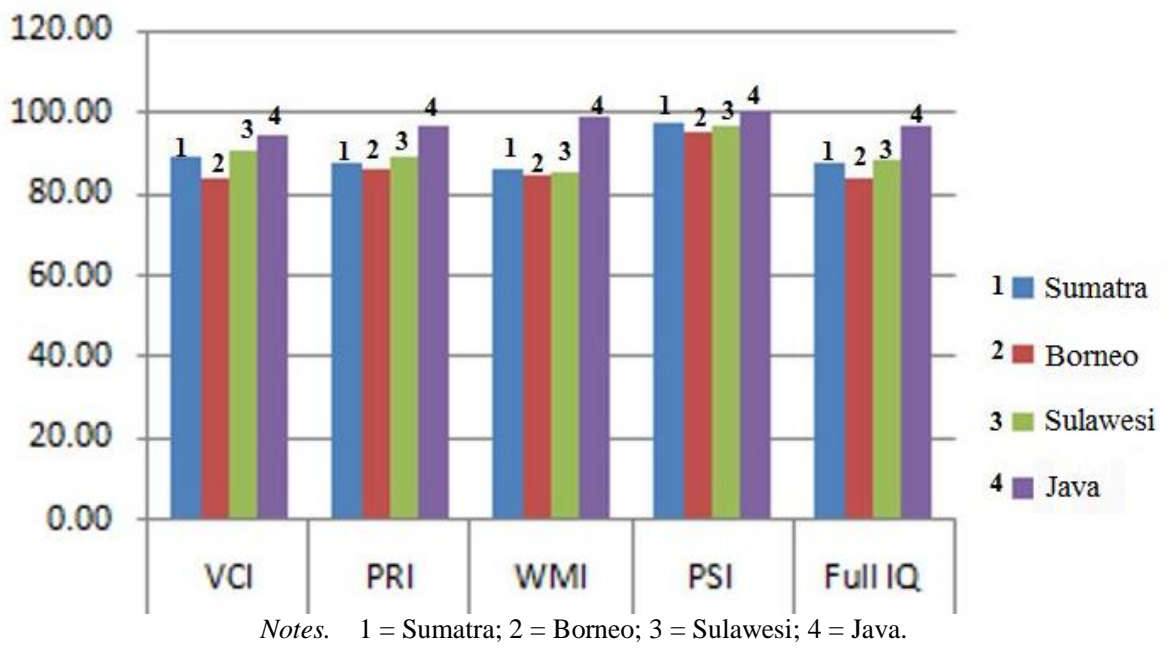

Figure 1. The WAIS-IV-ID index and FSIQ scores among samples from four islands.

Sumatra, Sulawesi, and Borneo islands. Although the reason for differences is still an open question, we suspect that the differences might be due to the conditions, access to education, and a general quality of life which are better in Java island than in the other three islands because the Java island is the center of urban development in Indonesia (Kuncoro, 2013). Heidhues (2008) stated that most areas in Borneo island were still covered with dense forests and therefore, the inter-city access was difficult. Similar conditions also occurred in Sumatra and Sulawesi island. Most areas in Sumatra island were highlands (Marsden, 1975) and most areas in Sulawesi Island were bays (Kementerian Penerangan Republik Indonesia, 1966). Based on this, Java island has more advantages than other islands allegedly because of easier access to education and health care, and better infrastructures and economic conditions. Therefore, as expected, almost all the subtest and index scores were significantly different among the Indonesian samples in four main islands.

For additional analyses, we assessed the differences of educational backgrounds because education could influence intelligence development (Nisbett, 2009). When education was included in the analyses, Verbal Comprehension (VCI), Perceptual Reasoning (PRI), and the Full-Scale IQ (FSIQ) were significantly different. Education was significantly influenced the VCI scores; indicating that the environment, in this case education, affects the index scores (Nisbett, 2009). Another reason that is potentially behind the differences on the VCI scores is the usage of regional languages rather than Indonesian language in daily life. The Indonesian Statistical Department
(BPS, 2010) reported that $79.45 \%$ of Indonesian people used regional language for daily conversation, thus, participants could be unfamiliar with the items shown to them or the items have different meanings in Indonesian language compared to everyday language. This might affect participants' VCI scores. Regardless the differences on the three indices, there were no differences on Working Memory (WMI) and Processing Speed (PSI) between islands and education based on the results of two-way ANOVA interactions. This might be due to different types of participants' occupations, such as nurses, teachers, daily workers, professionals, and seminarians. Participants' types of occupations should be carefully examined in further research and included in the analysis.

Based on the interaction effects of the two-way ANOVAs, we also found that education influenced participants' performances on VCI, PRI, and the FSIQ. In general, the higher the education, the better the performances on the three indices (Abad, Sorrel, Roman, \& Colom, 2016; Shuttleworth-Edwards et al., 2004). Based on the post hoc test on PRI, people with higher educational levels had better scores than people with lower educational attainments and the highest scores were the individuals who lived in Java Island. Rosselli and Ardila (2003) stated that people with higher educational attainments have a better performance on abstract thinking and problem-solving skills. Therefore, educational level should be considered as an important factor when interpreting an individual's intelligence test scores.

The results of the present study showed that the intelligence profiles of Indonesians residing in dif- 

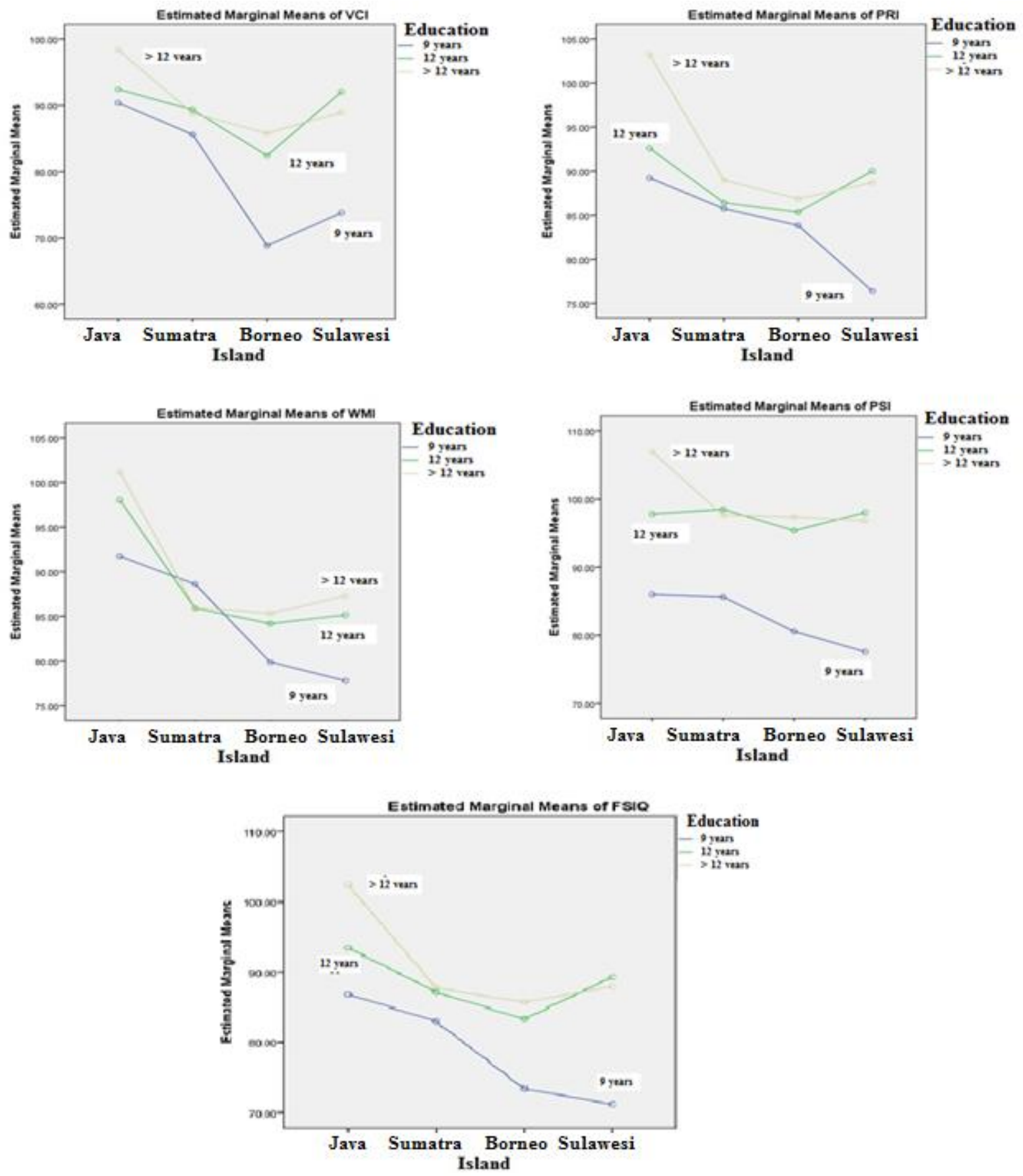

Figure 2. The WAIS-IV-ID index and FSIQ analysis between islands and education.

ferent islands were significantly different. This suggests that psychologists, psychometricians, researchers, and other practitioners in the field of psychology consider and provide different kinds of standardized norms when developing Indonesian psychological measurement tools. Based on the results in this present study, the standardized norms of the WAIS-IV-ID should be created based on different islands or different education attainments for the best test score interpretation. In addition, the results from descriptive statistics and additional analyses indicated that the standardized norms for the WAISIV-ID could be divided into Java Island and NonJava Islands, where the standardized norms for the three islands outside Java could be combined into one standardized norm to be used for people from 
outside Java. Both recommendations are made by considering the intelligence profiles' categories of the four index scores and the Full-Scale IQ scores using below average scores (80-89) and average scores (90-109) as suggested in the WAIS-IV-US standardized norms and other factors related to intelligence development, such as education, age, economic levels , and so forth (Santrock, 2013).

\section{Limitations and Suggestions}

This study has several limitations. First, the samples were drawn using convenience sampling. Further research should use cluster sampling for better representation of samples. Second, a similar type of study should consider ethnic factor because Indonesia consists of diverse ethnic groups. Third, future research should also consider participants' types of occupations, because each occupation has certain characteristics that can influence the intellectual ability of participants from different islands. Fourth, further research needs to include samples from Papua Island in addition to samples from other islands in order to represent the whole Indonesian population, which can be beneficial for the norm development of the WAIS-IV-ID.

\section{Conclusion}

In conclusion, the results of this study provide a solid basis for the development of standardized norms of the WAIS-IV-ID. This study also provides a recommendation for the government to maintain the priority of national development, especially development of infrastructures and education outside Java, which can influence people's cognitive development. The intelligence profiles and differences in cognitive functions that we found are not meant to differentiate Indonesians according to their test performances, but to provide an overview for a better interpretation of intelligence scores among Indonesians.

\section{References}

Abad, F. J., Sorrel, M. A., Roman, F. J., \& Colom, R. (2016). The relationship between WAIS-IV factor index scores and educational level: A bifactor model approach. Psychological Assessment, 28 (8), 987-1000. http://dx.doi.org/10.1037/pas0000228

Badan Pusat Statistik. (2010). Kewarganegaraan, su- ku bangsa, agama, dan bahasa sehari-hari penduduk Indonesia. Jakarta: Badan Pusat Statistik.

Badan Pusat Statistik. (2016a). Distribusi persentase penduduk menurut provinsi 2000-2014. Retrieved from http://www.bps.go.id/linkTabelStatis/view/i $\mathrm{d} / 1277$

Badan Pusat Statistik. (2016b). Indeks pembangunan manusia (metode baru). Jakarta: Badan Pusat Statistik. Retrieved 17 February 2016 from http:// bps.go.id/linkTableDinamis/view/id/1211

Baxendale, S. (2011). IQ and ability across the adult life span. Applied Neuropsychology, 18, 164-167.

Baxendale, S., McGarth, K., \& Thompson, P. J. (2014). Epilepsy \& IQ: The clinical utility of the wechsler adult intelligence scale-fourth edition (WAIS-IV) indices in the neuropsychological assessment of people with epilepsy. Journal of Clinical and Experimental Neuropsychology, 36(2), 137-143.

Camara, W. J., Nathan, J. S., \& Puente, A. E. (2000). Psychological test usage: Implications in professional psychology. Professional Psychology: Research and Practice, 31(2), 141-154.

Cockcroft, K., Alloway, T., Copello, E., \& Milligan, R. (2015). A cross-cultural comparison between South African and British students on the wechsler adult intelligence scales third edition (WAIS-III). Frontiers in Psychology, 6(297), 1-11.

Corder, G. W., \& Foreman, D. I. (2009). Nonparametric statistics for non statisticians. New Jersey: John Wiley \& Sons, Inc.

Gravetter, F. J., \& Wallnau, L. B. (2013). Statistics for the behavioral sciences. Wadsworth: Cengage Learning.

Groth-Marnat, G. (2010). Handbook of psychological assessment. New Jersey: John Wiley \& Sons.

Harrison, A. G., Armstrong, I. T., Harrison, L. E., Lange, R. T., \& Iverson, G. L. (2014). Comparing Canadian and American normative scores on the Wechsler Adult Intelligence Scale-Fourth Edition. Archives of Clinical Neuropsychology, 29, 737-746.

Heidhues, M. S. (2008). Penambang emas, petani, dan pedagang di "distrik Tionghua" Kalimantan Barat. Jakarta: Yayasan Nabil.

Jumlah Sekolah Menengah Atas Kurang. (2015, 15 July). Kompas, pg. 12.

Kalimantan Barat Kekurangan 16.047 Guru. (2015, 21 July). Kompas, pg. 12.

Kementerian Penerangan Republik Indonesia. (1966). Propinsi Sulawesi. Makassar: Kementerian Penerangan Republik Indonesia.

Kuncoro, M. (2013). Economic geography of Indonesia: Can MP3EI reduce inter-regional inequali- 
ty? South East Asia Journal of Contemporary Business, Economics, and Law, 2(2), 17-33.

Kusharjanto, H., \& Kim, D. (2011). Infrastructure and human development: The case of Java, Indonesia. Journal of the Asia Pacific Economy, 16(1), 111-124.

Lichtenberger, E. O., \& Kaufman, A. S. (2009). Essentials of Wais-IV assessment. New Jersey: John Wiley \& Sons.

Lynn, R. (2006). Race differences in intelligence. Washington: Washington Summit Publishers Augusta.

Marsden, W. (1975). The history of Sumatra. Kuala Lumpur: Oxford University Press.

Nisbett, R. E. (2009). Intelligence and how to get it. New York: W. W. Norton \& Company, Inc.

Nisbett, R. E., Aronson, J., Blair, C., Dickens, W., Flynn, J., Halpern, D. F., \& Turkheimer, E. (2012). Intelligence new findings and theoretical developments. American Psychological Association, 67 (2), 130-159.

Rosselli, M., \& Ardila, A. (2003) The impact of culture and education on non-verbal neuropsychological measurements: A critical review. Brain and Cognition, 52(3), 326-333.

Rushton, J. P., \& Jensen, A. R. (2005). Thirty years of research on race differences in cognitive ability. Psychology, Public Policy, and Law, 11(2), 235-294.

Santrock, J. W. (2013). Life-span development. New
York: McGraw-Hill.

Shuttleworth-Edwards, A. B., Kemp, R. D., Rust, A. L., Muirhead, J. G., Hartman, N. P., \& Radloff, S. E. (2004). Cross-cultural effects on IQ test performance: A review and preliminary normative indications on WAIS-III test performance. J. Clin. Exp. Neuro-psychol, 26(7), 903-920. Retrieved from http://dx.doi.org.ru.idm.oclc.org/10.1080/ 13803390490510824

Suwartono, C., Halim, M. S., Hidajat, L. L., Hendriks, M. P., \& Kessels, R. P. (2014). Development and reliability of the Indonesian wechsler adult intelligence scale-fouth edition (WAIS-IV-ID). Psychology, 5, 1611-1619.

Suwartono, C., Hendriks, M. P. H., Hidajat, L. L., Halim, M. S., \& Kessels, R. P. C. (2015). Structural validity of the Indonesian wechsler adult intelligence scale - Fourth Edition (WAIS-IV-ID). Manuscript submitted for publication.

Suwartono, C., Hendriks, M. P. H., Hidajat, L. L., Halim, M. S., \& Kessels, R. P. C. (2016). External validity of the Indonesian wechsler adult intelligence scale - Fourth Edition (WAIS-IV-ID). Мапиscript submitted for publication.

Urbina, S. (2004). Essentials of psychological testing. Hoboken: John Wiley \& Sons, Inc.

Wechsler, D. (2008). Wechsler adult intelligence scale-fourth edition administration and scoring manual. San Antonio, TX: Pearson.

\section{Acknowledgement}

The data in this research is part of a research project supported by research grants from Indonesian Ministry of Education and Culture under the International Research Collaboration and Scientific Publication in 2013 - 2015 number 085/SP2H/PL/DIT.LITABMAS/V/2013, 207/K3/KM/2014, and 094/K3/KM/2015. The WAIS-IV (Copyright (C) 2008 NCS Pearson, Inc.). Indonesian translation copyright (C) 2013. Translated, adapted, and reproduced with permission of the publisher. All rights reserved). The authors acknowledge the contribution of institutions in Java (Jayamas, Atjong Tex, PT Astra International Tbk., Yayasan Spiritia, Bright Consulting, PDA Consulting, Yayasan Tri Asih, Universitas Pelita Harapan, Universitas Widya Mandala, Universitas Ciputra, Universitas Matana, Biro Psikologi Inner Power, Perpustakaan ICBC Yogyakarta), Sumatra (Universitas Bina Darma, Akademi Kebidanan Rizki Patya, Biara San Damiano, Biara Charitas Laverna, Biro Psikologi Magna Penta, Kapolresta Pekanbaru), Borneo (Klinik Millenia, RS St. Antonius, Paroki St. Agustinus, SMA. St. Paulus, SMAK Immanuel, dan SMA St. Ignatius Singkawang), and Sulawesi (Universitas Atma Jaya Makassar, Universitas Negeri Makassar, Skolastikat MSC Hati Kudus) and a lot of individuals for their help with current data collection. Our gratitude goes to all testers and participants for their contribution in data collection of this research. 